\title{
Aminata Sow Fall's Works: A Compendium of Development-Oriented Issues
}

\author{
Dr (Mrs) Irene Udousoro
}

Department of Foreign Languages University of Uyo, Uyo, Nigeria

Email: iudousoro@yahoo.com

\author{
Doi:10.5901/mjss.2013.v4n6p67
}

\begin{abstract}
Aminata Sow Fall is celebrated not only in her home country, Senegal, as a committed writer on issues that tend towards personal and national development but worldwide. Her works have won international awards and have also been translated in major languages of the world like English, Russian, Italian, Finnish, etc. Her works reflect not only sociopolitical, economic and cultural realities of the Senegalese society but those of the African society in general. This article seeks to highlight some of Aminata Sow Fall's reflections on the Senegalese society and by extension the entire human race. Some of her themes include respect for and promotion of interpersonal relationships in spite of class differences \{ $L$ a grève des battus), African cultural values (L'appel des arènes), projects geared towards self-employment and self-enhancement ( Festins de la détresse) among others. It is also intended to stir up further researches on Aminata Sow Fall's works and those of other African authors whose writings not only showcase Africa's rich cultural heritage but also contribute towards the concept of world literature. There are many lessons to learn from her works and this paper, apart from celebrating this successful but unassuming author, hopes to contribute to the propagating of the author's ideologies to her teeming reading public all over the world.
\end{abstract}

Keywords: Aminata Sow Fall, Development, African Literature in French, Style, Senegalese Society

\section{Introduction}

In the broadest sense of the word, literature, according to Makouta-Mboukou $(1970: 9,10)$, is all about expressing, amplifying a people's voice, making them become conscious of their existence, their values, their past, the possibilities open to them for struggles for survival and rehabilitation. This could be achieved either orally or in written form, according to the source.

From the pre-colonial times until now, African intellectuals have significantly influenced their readers, whether local or international, through creative writing which permits them to 'express their particular social consciousness and to give persuasive form and force to their ideological position' (Irele, 1969:1). Their literature, especially from the standpoint of themes and language use clearly translates their ideological inclinations and attests to their social relevance.

African literature in general has a history, a tradition and names that can hardly be forgotten or ignored. Names like Birago Diop, Bernard Dadié, Camara Laye, Cheikh Hamidou Kane, Ahmadou Kourouma, Ferdinand Oyono, Mongo Beti, Sembène Ousmane, Léopold Sédar Senghor, among others, are written in gold as far as African literature of French expression is concerned. Their writings have immensely contributed to project the rich cultural African heritage and values as well as served as a means of expression of the struggles for the real African identity or 'Africaness'.

Carole Boyce (cited by Gadjigo, 1994:26) claims that until the middle of the 1970's, African literature was traditionally dominated by male authors and critics, thus Africa was only known through the literary works of male authors. Aminata Sow Fall's first novel, Le Revenant, appeared in the literary scene in 1976, making her the first francophone female writer. Since then, she has made a mark in the $20^{\text {th }}$ and $21^{\text {st }}$ Centuries as an author whose works reveal the social behaviour of the Senegalese people and how such behaviour has affected the entire Senegalese society adversely from the socio-cultural, economic and political points of view. Aminata Sow Fall's works can indeed be summed up as a manifesto of social change.

So far, women have, to a reasonable extent, lent their voice to the literary discourse in Africa. Female authors like Mariama Bâ and Aminata Sow Fall are highly celebrated not only in Africa but also in the international literary scene. They are indisputably the forerunners of female African writers of French expression and have in varying degrees, inspired or influenced a teeming younger generation of female authors like Fatou Keita, Calixthe Beyala, among others. 
This paper intends to $\mathrm{x}$-ray Aminata Sow Fall's works with a view to bringing to focus her immense contribution to the growth and development of not just African literature but the African society as a whole through an insight into the Senegalese situation.

\section{General Overview of Aminata Sow Fall's Novels}

Aminata Sow Fall has authored seven novels which have earned her international recognition and awards in some cases. The novels are: Le Revenant (1976), La Grève des battù (1979), L'Appel des arènes (1982), L'Ex-père de la Nation (1987), Le Jujubier du Patriarche (1993), Douceurs du bercail (1998), Festins de la détresse.

Sow Fall's literary career started in 1976 with her first novel Le Revenant but it was her second novel, La Grève des battù that launched her into limelight and celebrity. Apart from being preselected by the Goncourt jury in 1979 and the Grand prix littéraire de L'Afrique in 1980, La Grève des battù is translated in English, Russian, Chinese, German, Swedish, Danish and Finnish, thus attesting to its reception world-wide. L'Appel des arènes followed in 1982, also preselected by the Goncourt jury in 1982, as well as the Prix International Alioune Diop Pour Les Lettres Africaines awarded by L'Institut Culturel Africain (L'ICA).

\section{Major themes in Aminata Sow Fall's Novels}

Aminata Sow Fall's novel's treat a variety of themes which one could sum up as a biting criticism of the Senegalese society. She believes a writer should not relish in the Art for Art's sake, but his or her work should serve as a medium to communicate messages destined to transform the society from where it emanates. This fact is re-echoed by Gugelberger (cited by Adeleke, 1998:26) as follows:

Within the African context, writers cannot and should not afford themselves the luxury of writing literary pieces just for the sake of art without showing concern about the plethora of problems facing Africa and her people. The form of the concern thus expressed depends on factors ranging from the writers' interests to their inclinations and training among other factors.

In her first novel, Le Revenant, A. S. Fall highlights the Senegalese people's cupidity for money and extravagant living. She presents a situation where Bakar, a young employee of the Postal Services, in order to please his family entourage, lives above his means and in order to maintain a certain level of life, steals public funds, which earns him imprisonment. Bakar sets up his family as a way of fighting back for their having pushed him into dishonour and then abandoning him to face the odds alone. In her most recent novel, Festins de la détresse, Aminata Sow Fall, through one of her characters, Weurseuk, paints another picture of the Senegalese society, that of laziness and idleness among a certain class of people who enjoy and actually look forward to funeral ceremonies so they can feed themselves and their families. Another character in the same novel, Professor Diop, presents another side of the decay in the Senegalese society. As a renowned medical doctor, he obtains grants from international organizations to assist AIDS patients, particularly babies, but converts these grants to his personal use. The novelist sees the Senegalese society as being too materialistic, a situation leading generally to mismanagement of public funds and crime, which vices are inimical to the socio-economic development of any society.

The award-winning La Grève des battù presents a town, which critics believe is Dakar, the capital of Senegal, but which in fact could be any major African city. The administrators in the said town claim the capital is defaced, filthy and unattractive because of the beggars, 'human wastes' (p.5) who station themselves in strategic positions in the town to beg for alms. As a result of their (the beggars') filthy condition and importunity, the administrators claim the country has lost huge profits it could have made from investments in tourism. The beggars are therefore harassed and driven away to an encampment about two hundred kilometers from the town.

The beggars, conscious of their importance and in fact relevance in the society, decide to fight back. Their strike has far reaching consequences on Mour Ndiaye, the man behind the beggars' marginalization, but whose success at the polls as Vice President of the country depends on the beggars' cooperation with him. Mour fails the election, and learns too late that the 'strong' need the 'weak' and less privileged to survive. A. S. Fall's implicit recommendation that every man has a right to live without fear of oppression by the more privileged is quite obvious in La Grève des battù.

The condition of the African women as well as the conflict of generations are also expressed in Sow Fall's novels. Lolli, in La Grève des battù, accepts her husband's second marriage to Sine with calm resignation because traditional 
African values condition women to believe that it is not proper for a woman to oppose her husband even when she is hurt by his misdemeanours, a situation which Raabi, her daughter can neither understand nor accept. Sine, on the other hand, challenges Mour's attempt to see her as a piece of furniture in the house- without any say or choice as far as the man's whims and caprices are concerned.

In most African societies, infertility in marriages is almost always attributed to women, while the men silently exonerate themselves from the scourge. In Le Jujubier du patriarche, a young woman, Bouri, who is childless, but who is declared 'normal' after series of fertility tests is advised by an older and more enlightened woman, Naarou, to confront her husband with the results of the tests and the fact that he is the cause of their childlessness! Bouri ends up being divorced by her husband who,understandably, cannot stand the insult and the humiliation by a 'mere' woman! Recent medical reports show that the male factor is increasingly being responsible for infertility in most couples, and African men must learn to accept this truth.

Diattou in L'appel des arènes ridicules herself by trying to imitate the whites in her dressing, eating habits and the kind of western education she imposes on her only son, Nalla, who resists her vehemently. Diattou is equally resisted and even ostracized by other women in her community. Nalla's resistance to his mother's attempt to 'westernize' him is seen by Sylvie Broido et al (1986: 61) as a reverse of the usual antagonism of the parents/children conflict which A. S. Fall highlights as the problem of this transitional generation confronted with the double protest of elders and the younger ones, that is, elders versus the younger ones and vice versa, from the point of view of values and comportment.

For Sow Fall, there is certainly hope for the African woman. In her novel, Douceurs du bercail, she attempts to paint the picture of an African woman with dignity through her female character, Asta. Asta, while on official trip to Europe, was arrested, detained and repatriated unjustly. Back at home, she decides that there is more dignity in being self-reliant. Through team-work, she sets up an agricultural project which she finds gratifying in the final analysis. Another character, Biram, in Festins de la détresse, a qualified medical doctor, though not a woman, after several unsuccessful attempts to secure an employment with a government hospital, decides to set up his private clinic, which becomes very rewarding in the course of time. A. S. Fall obviously supports self-employment by individuals who do not have to only depend on government jobs for survival.

For known critics like Lilyan Kesteloot, A. S. Fall is a feminist author who has no pity for women. In other words, she promotes women's causes without necessarily degenerating into pitying them. Some critics feel A. S. Fall is not a feminist writer par excellence. The author herself says she is not a female writer the way people look at it. According to her, she is not a militant feminist neither does the 1975 conference have anything to do with her writing. She sees writing rather as un 'act of witnessing, recording, a way of filtering the social reality of the moment' (Gadjigo, 1994: 28). The fact that one is a female writer does not necessarily mean one must have feminist inclinations. A. S. Fall has the right to exercise her writer's liberty and not necessarily fit into the feminist mould.

As regards the issue of self-employment, perhaps Asta's and Biram's bold step towards setting up their own businesses is A. S. Fall's way of suggesting that those who see rural drift as a way out of deprivations in the rural areas should have a rethink. In her novels, Le Revenant, L'Appel des arènes, Douceurs du bercail, those who resort to rural drift suffer untold hardship, embarrassment and dehumanization. There is dignity in being involved in the socio-economic development of one's country whether in the rural areas, at the urban or national levels.

Political questions are also raised in A. S. Fall's novels like L'Ex-père de la Nation, Le Jujubier du patriarche, Douceurs du bercail. In L'Ex-père de la Nation, an ex-president of an African nation, a fallen dictator, reflects on his political career, after he had managed to escape from a bloody coup. He was elected president of the Republic by a vast and crushing majority and was hoping that through his leadership his country would enjoy or experience socio-economic development and political stability. The reverse was however the case; his regime turned out to be dictatorial, oppressive and full of deprivations and misery particularly for the masses and finally ended up in bloodshed. Le Jujubier $d u$ patriarche highlights personal ambition as the driving force behind people forming or belonging to political parties. One of the characters in the novel, Idy, reveals the truth that 'democracy is fashionable' (p.58), implying that most countries of the world claim to have democratic governments, but very few, particularly African nations, can be said to be truly democratic.

The problem most African countries are facing is partly because some politicians, especially those in the ruling party, desire and come to power at all cost, irrespective of what the masses believe or expect from leadership. Implicitly, the author sees a review of the electoral processes as inevitable if the democratic experience must succeed.

Another political issue raised in Douceur du bercail is that of racial discrimination or modern apartheid in some countries of the world. The former colonialists still have easy and free access into the countries they once colonized either as tourists or investors but deny the Africans in particular, entry into their own countries because of one bias or 
suspicion or the other. Even though there has been abuse of visa privileges by some unscrupulous persons, the fact remains that there are some travelers who have genuine reasons for leaving their countries and should not be denied visas into the countries of their choice. Asta's arrest, detention and eventual deportation might well be the author's message that 'eldorado is not found at the end of the exodus but in the bowels of our land' (P. 87).

As many critics generally agree, A. S. Fall's novels reflect the Senegalese socio-economic and political realities with a view to challenging the Senegalese and Africans as a whole to change their ways for the better.

\section{Style in A. S. Fall's novels}

Aminata Sow Fall can hardly be identified with any of her novels from the way she writes. None of her works can be said to reflect her personal experiences. Her seven novels are characterized by the third person narration which generally projects the author as an observer, thereby guaranteeing a certain degree of objectivity.

From the point of view of language, Sow Fall shows evidence of a level of erudition and ease as far as communication in French is concerned. One observes a good mastery of the various registers of the French language on the part of the author, reflecting the social status or class of the various characters in the novels.

Sow Fall is very humorous. She knows how to throw her readers into fits of laughter when the tension is very high. One such case is when Mour Ndiaye went to the beggars in their encampment to persuade them to come back to the city so he could 'perform' his sacrifice. The beggars jubilated over the currency notes that Mour was throwing to them, giving the impression that Mour had bought them over; but Mour was deceived. Sow Fall's use of irony in the show-down by the beggars is pungent, confirming the wolof proverb: 'Nit nitey garab am' (cited by Mfon, 1977: 41, 42), implying that we need one another to survive!

Another humorous scene is recorded in Douceurs du bercail in a telephone conversation between Anne (Asta's friend) and a secretary in Asta's work place back in Africa. The Secretary's responses, though very irritating, are very funny and probably help to release tension (pp.58-59).

Still from the point of view of language use, Sow Fall introduces a lot of wolof words and expressions into her novels. It could be argued that some of these linguistic elements may not have equivalents in the French language but can be understood contextually. Being who she is, a writer with a message or messages, A. S. Fall may well be implying that the contact between the French and the Senegalese, the marriage of convenience, imposed by circumstances, is permanently engraved in history. Apart from that, the use of wolof in Sow Fall's works simply highlights the sociolinguistic realities of the Senegalese society.

One also observes the preponderance of elements of African folklore like songs, poems, proverbs, short stories, etc. in Sow Fall's novels. L'appel des arènes, Le Jujubier du patriarche seem to be the richest in elements of folklore; even in L'Ex-père de la nation, with its political undertone records a good number of folk songs. For A. S. Fall, no doubt, Africa is a continent with a rich cultural heritage, a past and traditions that should be preserved and handed to posterity.

Characterization is another very outstanding feature of Aminata Sow Fall's novels. Whether male or female, young or old, rich or poor, Sow Fall's characters are more or less carriers of her visions and express her thoughts one way or the other. They are self-willed, intense, determined, people who pull out of a debilitating social condition or status quo with a view to ushering in new values. In this regard, Nalla (L'appel des arènes), is a bridge between the Senegalese and western values; Bakar (Le Revenant), is an instrument of judgment of a corrupt and materialistic society; the beggars in La grève des battù stand to condemn injustices and marginalization in the society; Asta (Douceurs du becrcail) and Biram in (Festins de la détresse) are an expression of hope for an African society where individuals look inwards for selfactualization but for collective interests.

A lot can be achieved by Africans within the shores of Africa. Africans should be discouraged from looking elsewhere for their accomplishments. One is nothing but an 'outsider' outside of his own home or land. This seems to be Sow Fall's views, using Asta and Biram as case studies.

\section{Conclusion}

Although Aminata Sow Fall is a female African writer, her writings go beyond feminist interests and preoccupations to cover the socio-economic and political concerns of her country, Senegal. She is objective in her presentation of the Senegalese society which we view as a microcosm of Africa. The problems of marginalization of the less privileged by the well-placed in the society, rural drift, 'political opportunism and selfishness' according to Arungwa (cited by Obinaju, 
1995:307), materialism, among others, continue to plague most African countries many years after their independence from colonial rule. However, the picture is not totally grim.

Youssouf Cissé (1986: 18) claims that Africa is endowed with natural resources such as crude oil, iron, copper, gold, diamond, manganese, phosphate, solid minerals as well as forest resources. According to the source, if these resources are tapped to the benefit of Africans, there would be more stability in Africa, where there is currently very serious population explosion. Besides, the relationship between the black continent and Europe, where black immigrants constitute a real menace, would be sanitized. For Aminata Sow Fall, Africans have the potential to be self-reliant like Asta in Douceurs du bercail and Biram in Festins de la détresse, and to achieve self-actualization through determination and hard work. The dignity of the Africans lies in building a better image for themselves abroad through their involvement in nation building and development at home.

Since the publication of Sow Fall's novel, Le Revenant, Gadjigo (1994:17), claims that the number of literary works has not only increased, but their distribution in the African continent and in the world has diversified. Through her works, A. S. Fall has proved beyond doubt that female writers do more than just decry societal injustices to women. A lesson and a legacy for African men and women in this age of globalization: the world is looking for women who are not petty and men who are not self-centered but for people who can assert themselves through intellectualism and professionalism, not forgetting the lesson on mutual help in La Grève des battù!

\section{References}

Adeleke, J. (1998): 'The literary artist as a social critic: Aminata Sow Fall's example, in Literature, Ideology and Society Ed. Aduke Adebayo, Segun Odunuga, Ibadan: AMD Publishers, pp.126-138.

Broído, S; Moock, S; Nataf, A; Yvé, N (1986): 'A lire in Ecrivains de Langue Française, Notre Librairie, No. 82, pp.54-62.

Fall, A. S. (1976) : Le Revenant, Dakar : Les Nouvelles Editions. (1979) : La grève des battù, Dakar : Les Nouvelles Editions. (1982) : L'appel des arènes, Dakar : Les Nouvelles Editions. (1987) : L'Ex-père de la Nation, Dakar : Les Nouvelles Editions. (1993) : Le jujubier du Patriarche, Dakar: Editions Khoudia. (1998): Douceurs du bercail, Dakar: Les Nouvelles Editions Ivoiriennes. (2005) : Festins de la détresse, Editions d'en bas.

Gadjigo, S. (1994) : 'L'œuvre littéraire d'Aminata Sow Fall face à la critique' in Notre Librairie, No. 118, Paris : CLEF, pp.25-28.

Makouta-Mboukou, J. P. (1970)) : Introduction à la littérature noire, Yaoundé : Editions CLE.

Mfon, I. O. (1997) : 'L'Enonciation dans l'œuvre d'Aminata Sow Fall' (Unedited Ph.d Thesis, University of Calabar, Calabar).

Obinaju, J. N. (1995) 'Human rights echoes in Aminata Sow Fall's The Beggars' strike, Budapest: Neohelicon XXII/1, pp. 295-310. 
